\title{
The use of financial management practices by small, medium and micro enterprises: a perspective from South Africa
}

\author{
Pradeep Brijlal, Samuel Enow and Eslyn B.H. Isaacs
}

\begin{abstract}
:
This paper reports on an investigation of financial management practices used by small, medium-sized and micro-enterprises (SMMEs) in South Africa. It was found that more than half the SMMEs examined use external accounting staff to prepare accounting reports and more than 60\% rely on external accounting staff to interpret and use accounting information. A majority of the SMME owners were found to lack interpretation skills and an awareness of how to use information from financial statements. An implication of this study therefore is that policy makers, business support organizations, banks and academic institutions need to focus on educating SMMEs more effectively in financial management, thereby mitigating the risk of cash flow problems and business failure.
\end{abstract}

According to the Organisation for Economic Cooperation and Development (OECD, 2006), small, medium-sized and micro-enterprises (SMMEs) and entrepreneurship are now recogni zed worldwide as key sources of dynamism, innovation and flexibility. SMMEs are responsible for most net job creation, making an important contribution to productivity and economic growth; they are the logical 'kick-start' mechanism for job creation and future prosperity in the country (FaLOki, 20 12) and alleviation of poverty (Berry et al, 2002).

Since 1996, SMMES in South Africa have been actively promoted through the implementation of the National Strategy for the Development and Promotion of Small Business in South Africa to redress income redistribution, generation of employment and economic growth and ultimately alleviate poverty (Bruwer, 20 Io, Department of Trade and Industry, 2003). Many new SMMEs have been started in South Africa, contributing significantly to the economic growth of the country, to the extent of between $27 \%$ and $34 \%$ of the gross domestic product (GDP) and 72\% of all jobs in South Africa (Department of Trade and Industry, 2003, Department of Trade and Industry, 2008).

According to Sha (2006) the failure rate of SMMEs is very high during the first two years of the new start-up . Research by Petrus (2009), Tung and Aycan (2008) and Herrington and Wood ((2004) indicated that SMMEs fail because of lack of education and training, shortage of management skills, Jack of access to finance and lack of financial management competences. A 
shortage of financial management skills as a root cause of business failure is not a new phenomenon (Nayak and Greenfield, 1994), such a shortage being typical of SMMEs, in contrast to large and multi-national business enterprises where specialists are employed and modern technology is used to provide up-to-date data and information.

SMMEs, often owned and managed by the same person, have been found to be flexible in decision-making but lacking in internal expertise (Berry et $a /, 2006$ ). The informality of bookkeeping and the accounting information in SMMEs can complicate and prolong decisionmaking (Perren and Grant, 2000). SMME owners are often seen as a 'jacks of all trades', involved in all the key business functions such as marketing, human resource management, operations, public relations and financial management. While these functions are all equally important, this study focuses on financial management.

Proper financial management is one of the deciding factors with regard to the survival of SMMEs (Jayansankaran, 1999, Harif et al, 2010, Abdullah et al, 2009). A study by the International Finance Corporation (IFC, 2006) revealed that those involved with the management of SMMEs are aware of the importance of accounting information and when it is available they use it for a variety of purposes.

According to Padachi (2010) financial management has both internal and external aspects. Internally, it is concerned with (i) implementing and managing an accounting system and (ii) generating information for decision-making purposes. Externally, it is concerned with the ability to attract adequate financial resources. Efficient financial management practices are vital in SMMEs: they provide a historical analysis of the performance of the business, which can then be used to project potential future performance. Vijayakumar (2001) tares that optimal utilization of financial management practices could enhance the growth of SMMEs and contribute to improving the South African economy in general and to the realization of the objectives identified in the development and promotion strategy of the government (Department of Trade and Industry. 1995)

Table 1. SMME classification in South Africa.

\begin{tabular}{|c|c|}
\hline Category & Generic description \\
\hline Micro-enterprise & $\begin{array}{l}\text { 1-5 employees. Mainly informal, untaxed } \\
\text { and unregistered businesses. }\end{array}$ \\
\hline Small enterprise & $\begin{array}{l}6-50 \text { employees. At least one } \\
\text { management layer. }\end{array}$ \\
\hline $\begin{array}{l}\text { Medium-sized } \\
\text { enterprise }\end{array}$ & 51-200 employees \\
\hline
\end{tabular}

Source: Adapted from The Small Business Act of 1996 and DT1 (2008) Annual National SMME Summit. 
There is an extensive literature on the use of financial management practices by large companies (Pullen and Cooley, 1979, Lee and Filbeck, 2000). However, research on the application of financial management by SMMEs is scarce, especially in a developing nation such as South Africa. This study therefore investigates the usefulness and application of these techniques by SMMEs in South Africa.

The paper is organized as follows. First, by means of a literature review, we define SMMEs and financial management and provide an overview of financial management practices. We then summarize the research methodology and present the research results. In the final sections of the paper we discuss the findings and offer concluding remarks and suggestions for future research.

\section{Literature review}

The World Bank defines South African SMMEs by number of employees, in accordance with the National Small Business Act of 1995 and amendments introduced in 2003 through the Small Business Amendment Bill. The categories, as listed in Table I, were reviewed at the 2008 Annual National SMME Summit. The table combines small and very small enterprises into one category (labelled 'small enterprise') and does not include survivalist enterprises.

\section{Definition offinancial management}

Financial management is the management of the finances of a business in order to achieve the financial objectives of the business. McMahon and Davies (1994) define financial management as the function concerned with raising the funds needed to finance the enterprise's assets and activities, the allocation of these scarce funds between competing uses, and ensuring that the funds are used effectively and efficiently in achieving the enterprise's goals. According to Arm strong (1986), financial management is concerned with planning, budgeting and control techniques. Oduware (2011) adds that financial management entails planning for the future of a business enterprise. Brinckmann et al (20 I I ) define financial management as including managerial activities that concern the acquisition of financial resources and the assurance of their effective and efficient use to ensure a positive cash flow. Armstrong (200 I) posits that financial management is further concerned with the activities within a business that contribute to profit maximization. According to Firer et al (2004), the goal of financial management is to maximize the wealth of the firm's owners. This notion is supported by Keown et al (2002), who argue that financial management contributes to creating and maintaining the economic value of a business.

\section{Financial management principles}

Arm strong (200 I) identifies five principles of financial management: financial planning, financial accounting, financial analysis, management accounting and capital budgeting. Harif et al (2010) include working capital as a sixth financial management practice. In the same way that financial management practices are important to large and multinational enterprises, they are also important for SMMEs (Fatoki, 2012). 
Financial management can occupy the major part of a financial manager's time and attention (Gitman, 2003) and many business failures have been attributed to the inability of financial managers to plan and control properly the current assets and the current liabilities of their respective firms (Dodge and Robbins, 1992, Ooghe, 1998).

This study focuses on financial planning and control, financial accounting and financial analysis. These broad categories of practices are defined in the following sections.

Financial planning. According to Armstrong (2001) financial planning predict s the overall financial performance of a business and alerts management to the funds required, when they will be required and how much will be needed. The primary financial planning activities are: income forecasting, cash flow forecasting, determining financial resource requirements, and profit and dividend planning.

Financial accounting. According to Weygandt et al (2000), financial accounting is the process of identifying, recording and communicating the economic events of a business in order to communicate this information to interested parties. Armstrong (200 I) asserts that financial accounting records the financial transactions that have taken place in a business. The Information recorded is then communicated through accounting reports in the form of financial statements - a balance sheet, an income statement and a flow of funds statement, deemed to be the primary data sources for financial analysis.

Financial analysis. According to Nguyen (200 1), financial analysis is the process of evaluating the performance of a business and other projects using tools such as ratio analysis, payback period, net present value and internal rate of return. Investment in projects require s risk analysis and sensitivity analysis. Typical tools such as cost-benefit analysis, cost-effectiveness, sales mix analysis and cost-volume analysis can be useful. Financial analysis includes ratios such as current ratio, quick ratio, return on sales, debt ratio, inventory turnover and return on equity.

Financial practices of SMMEs and external advice. In a dynamic environment where businesses are growing, SMMEs tend to seek business and financial advice from external sources - for example, accountants. The market for advice, and in particular with regard to the regulations that affect SMMEs, is constantly changing, and this change in the market conditions for advice has led many accountants to provide a wider range of services to SMMEs. This has major implications for those accountancy practices seeking to engage with SMMEs (Blackburn et al, 2006, Blackburn et at, 2010). Over time, the amount and type of advice from accountants has evolved according to both the needs of SMMEs and the strategic intent of accountants (Doving and Gooderham , 2008).

The SMME-accountant / bookkeeper relationship is regarded by many as a necessity, because SMMEs are required to produce documentation -such as audited financial reports - to comply with government regulations; and SMMEs are obliged to engage accountants or accounting officers to produce these statements. Research has also 
demonstrated that the SMME-accountant relationship, established as a result of compliance work, has the potential to become a source of business advice and support (Blackburn et al, 20 Io) through the interpretation and analysis of financial statements.

According to a stud y by Nguyen (2001) on the financial management practices and profitability of small and medium-sized enterprises (SMEs) in Australia, 77\% of SMEs apply financial planning practices such as financial, operational, sales and cash budgets; whilst $83 \%$ frequently compare budgeted and actual results. All the 150 SMEs in Nguyen's study (2001) used accounting information systems to monitor and execute their accounting operations while $70 \%$ prepared and analysed their financial statements. According to Maseko and Manyani (2011), accounting systems provide a source of information to owners and managers of small businesses operating in any industry for use in the measurement of financial performance in areas such as costing, expenditure and cash flow, by providing information to support monitoring and control.

Ismail and Zin (2009) investigated the use of accounting information among Malaysian small and medium-sized non-manufacturing firms using a sample of 136 firms. They found that half the SMEs that prepared accounting information used computerized accounting systems and just over half sought financial advice from accounting firms. In addition, they found that $40 \%$ of the SMEs did not prepare a balance sheet.

Maseko and Manyani (2011) investigated the record-keeping practices for performance measurement and improving the financial management practices of SMEs in Zimbabwe. They found that due to a lack of accounting knowledge the majority of SMEs did not keep complete accounting records and concluded that there was inefficient use of accounting information. An earlier study by McMahon (1999) found that most SMEs did not prepare a complete set of financial statements; and some did not prepare any financial statements.

The need to prepare a complete set of financial statements increases as an entity progresses from small to medium size. It is at the medium-size stage that financial performance reporting will be useful to internal and external users. Externa l users include lenders and suppliers of raw material or finished goods. In most cases ownermanagers prepare financial statements in SMMEs and many are not financially literate: it is possible that they resort to this practice to avoid the cost of hiring accountants (Everaert et al, 2006).

Based on this literature review and given the scarcity of South African literature in the field of financial management, investigation of the financial management practices used by SMMEs in South Africa was regarded as important and this study therefore set out to determine the extent to which financial management practices are used by SMMEs in the Western Cape. In particular, the following were investigated:

1. The importance of the financial planning practices used by SMMEs;

2. The importance of the accounting information system used in SMMEs; and 
3. The extent to which financial analysis and reporting is used in SMMEs.

\section{Research methodology}

An exploratory study was conducted, mindful of the fact that financial information on SMMEs is not freely available in South Africa, unlike the case in developed nations. According to Babbie (2007) and Babbie and Mouton (2001), exploratory research is used to make preliminary investigations when few or no studies exist, with the aim of developing new ideas, seeking new insights and examining phenomena in a new light that will form the basis for further research. Descriptive research is aimed at observing and then classifying the elements being observed, to provide an accurate profile of the situation (Robson, 2002).

Primary data were obtained using a structured questionnaire with four sections:

1. Biographical information about the business and business owner-manager responsible for the financial managem ent matters;

2. Assessment of the importance of financial planning practices;

3. Assessment of the importance of the accounting information system; and

4. The extent to which financial analysis and reporting was used in the SMME.

Questions were answered using a 3-point Likert scale (some of the secondary questions required 'yes' or 'no' responses).

The selection of cases was based on the purposive sampling method. This resulted in the selection of participants that best fitted the objectives of the study. Due to cost and other factors, 100 SMMEs in the main trading areas of the city of Cape Town were contacted: in the event, 59 business owners-managers agreed to participate. The data retrieved from the questionnaires were analysed using descriptive and inferential statistics.

The following were implemented, to ensure reliability and validity.

- The questionnaire was adopted and adapted to the South African context from previous studies, such as those of Nguyen (2001) and Harif et al (2010).

- The content of the questionnaire included the most relevant financial management practices discussed in financial management textbooks.

\section{Research results}

Table 2 presents the biographical information on the SMMEs and owner-managers: as can be seen, the popular types of legal ownerships were sole proprietor (36\%) and close corporation (31\%). Forty-four per cent of the businesses were Jess than five years old. In South Africa, a partnership is not a popular form of business ownership, accounting for only $6 \%$ of the respondents in our survey. As of 2010, the Close Corporation Act became defunct and therefore no new close corporations could be established after that date. SMMEs that had been in operation for more than 10 years accounted for $34 \%$ of the 
businesses studied. The highest qualification for most of the owners was Grade 12 (42\%) and $58 \%$ had a post-Grade 12 qualification. Fifty-four per cent of the owners were responsible for the financial matters of the business and $64 \%$ had been exposed to some sort of financial management training.

Table 2. Biographical information.

\begin{tabular}{lc}
\hline & $\begin{array}{c}\% \text { of firms } \\
\text { surveyed }\end{array}$ \\
Status of the business & \\
Sole proprietorship & 36 \\
Partnership & 6 \\
Close corporation & 31 \\
Private company & 27 \\
Industry sector & \\
Manufacturing & 52 \\
Retail/wholesale & 48 \\
Age of the business & \\
Less than 2 years & 15 \\
2-5 years & 29 \\
6-10 years & 22 \\
More than 10 years & 34 \\
Person responsible for financial matters & \\
Owner & 54 \\
Internal accounting staff & 36 \\
External accounting staff & 10 \\
Educational qualifications & \\
Secondary school & 42 \\
Bachelor's degree & 26 \\
Honours degree & 12 \\
Master's degree & 3 \\
Diploma & 17 \\
Financial management training & \\
Never & 34 \\
Yes & 66 \\
\hline
\end{tabular}

\section{Financial planning}

The respondents were required to indicate the relative importance of the various aspects of financial planning in their business, as shown in Table 3. Key result s were that $80 \%$ of the owners felt that financial planning was very import ant; $59 \%$ prepared budgets; $69 \%$ were involved in the budgeting process and in interpretation of the budgets; and 63\% compared actual payments with budgeted amounts. Only 59\% applied financial planning techniques learnt in training and $64 \%$ used computerized financial reporting techniques. 
The business owners were asked to indicate their business objectives. The results showed that:

1.

2.

3.

4.

5.

6.
$64 \%$ were interested in profit maximization; $49 \%$ were interested in customer satisfaction; $48 \%$ were interested in sales maximization; $41 \%$ were interested in growth; $36 \%$ were interested in cost minimization; and $14 \%$ were interested in survival.

The typical types of budgets prepared in these SMMEs were: sales (41\%); overhead costs (34\%); labour (29\%); cash (25\%); and purchases (20\%). Furthermore, more than 60\% of the business owners were not involved in the actual production of the budget $\mathrm{s}$. This is a matter of concern, because budgeting is one of the most important planning tools with regard to avoiding business failure. Herrington et at (2010) revealed that $75 \%$ of businesses fail during the first two years of operations and the lack of a budget was among the main reasons for this to occur.

\section{Accounting information system}

Accounting information reporting was divided into four categories: financial matters; recording transactions; preparation of accounting reports and interpretation and using accounting information. SMME owners were requested to indicate who was responsible for each of the categories listed under the accounting information system (Table 4). Fiftyfour per cent of the SMME owners were responsible for financial matters and 44\% for recording transactions; 54\% used external accounting staff to prepare accounting reports; and $61 \%$ relied on such external staff to interpret and use the accounting information. A high percentage of the owners seemed to lack the ability to interpret and use information from financial statements.

Table 3. Financial planning practices.

\begin{tabular}{|c|c|c|c|}
\hline & \multicolumn{3}{|c|}{ Rating scale ${ }^{n}(\%)$} \\
\hline & 1 & 2 & 3 \\
\hline How important is financial planning? & 15 & 5 & 80 \\
\hline How regularly does your business prepare its financial budgets? & 25 & 15 & 59 \\
\hline How involved is the owner-manager in preparing financial budgets? & 20 & 11 & 69 \\
\hline How involved is the owner-manager in interpreting and using financial budgets? & 20 & 11 & 69 \\
\hline How important are the financial budgets in providing useful information for decision making purposes? & 20 & 4 & 76 \\
\hline How regularly does your business compare budgeted and actual results? & 24 & 13 & 63 \\
\hline How regularly are financial planning techniques applied in financial analysis in your business? & 19 & 22 & 59 \\
\hline How computerized are financial reporting and analysis practices in your business? & 29 & 7 & 64 \\
\hline
\end{tabular}

"Note: $1=$ low importance; 2 =not sure; 3 =high importance. 


\begin{tabular}{lllll}
\hline Table 4. Accounting information system responsibilities. & \\
\hline & Financial matters (\%) & $\begin{array}{l}\text { Recording transactions } \\
(\%)\end{array}$ & $\begin{array}{l}\text { Preparing accounting } \\
\text { reports (\%) }\end{array}$ & $\begin{array}{l}\text { Interpreting and using } \\
\text { accounting information } \\
(\%)\end{array}$ \\
& & & 27 & 27 \\
Owner & 54 & 34 & 19 & 12 \\
Internal accounting staff & 36 & 22 & 54 & 61 \\
External accounting staff & 10 & & & \\
\hline
\end{tabular}

The SMME owners were asked to indicate their view of the importance of the accounting information system (Table 5). Eighty-five per cent of the businesses had a formal accounting system and $71 \%$ used computers (limited to recording business transactions). Respondents were also asked to provide feedback on the importance of their accounting information systems. Eighty per cent indicated the importance of accounting information in making decisions that had led to the success of their business; $69 \%$ compiled and updated financial information on a monthly basis; $66 \%$ of the owners were involved in interpreting and using accounting information; $71 \%$ of the firms had computerized accounting systems; and $80 \%$ of the owners found the accounting systems to be useful in making decisions.

\section{Financial reporting and analysis}

Bookkeeping alone, without preparing financial reports, is unlikely to be a fundamental factor in aiding decision making. As such, the efficiency of financial planning is dependent on the type of accounting system used in a business. The balance sheet, income statement, cash flow statement and flow of fund statements are the most important documents for reporting and analysis. The present research revealed that an income statement was prepared in $85 \%$ of the businesses, a balance sheet and cash flow statement in $47 \%$; and flow of funds in only $10 \%$.

The study also sought to establish who was responsible for preparing and analysing financial statements. As noted in Table 6, 54\% of SMME owners were responsible for the financial matters of the business and $64 \%$ obtained the services of external accountants for the interpretation, preparation and analysis of financial statements. 
Table 5. Efficiency of accounting information system.

Efficiency practices

Rating scale* $(\%)$

How important is your accounting information system to the success of the business? How frequently does your business prepare its accounting reports?

How does an accounting information system in your business update the business transaction?

What is the owner-manager's involvement in preparing accounting information?

What is the owner-manager's involvement in interpreting and using accounting information?

How acceptable is your business's accounting information system?

Is your business's accounting information system useful in making decisions?

How computerized is your business's accounting information system?

$\begin{array}{rrr}1 & 2 & 3 \\ 8 & 12 & 80 \\ 19 & 12 & 69 \\ 19 & 12 & 69 \\ 32 & 19 & 49 \\ 22 & 12 & 66 \\ 19 & 12 & 69 \\ 10 & 10 & 80 \\ 24 & 5 & 71\end{array}$

*Note: 1 =low; 2 =undecided; $3=$ high.

Table 6. Responsibility for preparing and analysing financial statements.

\begin{tabular}{llll}
\hline & Financial matters & $\begin{array}{l}\text { Interpreting and using } \\
\text { accounting information }\end{array}$ & $\begin{array}{l}\text { Preparing financial } \\
\text { statements }\end{array}$ \\
Owner & 54 & 24 & 24 \\
Internal accounting staff & 36 & 12 & 12 \\
External accounting staff & 10 & 64 & 64 \\
\hline
\end{tabular}

Table 7. Efficiency of financial reporting and analysis.

\begin{tabular}{|c|c|c|c|}
\hline \multirow[b]{3}{*}{ How does your business regard financial reporting and analysis? } & \multicolumn{3}{|c|}{ Rating scale* $(\%)$} \\
\hline & 1 & 2 & 3 \\
\hline & 22 & 7 & 71 \\
\hline How frequently does your business prepare financial statements? & 20 & 17 & 63 \\
\hline How involved is the owner-manager in preparing financial statements? & 27 & 19 & 54 \\
\hline How involved is the owner-manager in interpreting and using financial statements & 24 & 10 & 66 \\
\hline How useful are the financial statements of your business in providing information for decision making? & 14 & 8 & 78 \\
\hline How frequently does your business analyse financial statements? & 17 & 17 & 66 \\
\hline How useful are financial ratios applied in financial analysis of your business? & 27 & 14 & 59 \\
\hline How computerized are the financial reporting and analysis practices in your business? & 24 & 7 & 69 \\
\hline
\end{tabular}

Note: $1=$ low; $2=$ unsure; $3=$ high

The SMME owners were asked to indicate the extent to which they undertook financial reporting and analysis, as shown in Table 7. It is clear that in a large number of the businesses financial reporting and analysis practices were rated highly. Seventy-one per cent attached high importance to financial analysis and reporting; $78 \%$ attached high importance to the use of financial statements for decision making; $60 \%$ were involved in interpreting and analysing financial statements; and 63\% of the SMMEs prepared financial statements on a frequent basis. One means of analysing financial statements is through ratio analysis. The ratios most frequently used are: current, quick, debt, debt-to-equity, inventory turnover, return on sales, return on assets and return on equity. Respondents were asked to indicate the ratios they used to analyse their businesses (see Table 8): it can be seen that the SMME owners used ratios to a limited extent. The two main ratios used were the current ratio (36\%) and return on sales (30\%). These low percentages could be attributed to the lack of knowledge among SMME owners about the power of ratio analysis as a tool for assessing and improving business performance. 


\begin{tabular}{ll}
$\begin{array}{l}\text { Table 8. Assessing financial statements using ratio } \\
\text { analysis. }\end{array}$ \\
\hline \\
$\begin{array}{ll}\text { Businesses using ratios as a } \\
\text { means of analysis (\%) }\end{array}$ \\
Current ratio & 36 \\
Return on sales & 30 \\
Debt-to-equity & 14 \\
Inventory turnover & 13 \\
Quick ratio & 11 \\
Return on equity & 7 \\
\hline
\end{tabular}

\section{Discussion}

It is widely accepted that a lack of proper financial management contributes to business failure, irrespective of whether it results from Jack of access to financial resources or lack of expertise. Two issues emerge from Table 2: (i) approximately 54\% of the owners were responsible for financial matters, and (ii) $56 \%$ of the owners who were responsible for financial matters had attended some form of financial management training. Berry et al (2002) refer to relevance and competence as drivers of implementing and managing financial matters in a business. Some owners are often so engaged in trying to generate money through sales that they do not always understand the relevance (and importance) of financial matters; others might ignore financial management practices because they lack financial competence. Whilst 58\% of the SMME owners surveyed had a post-Grade 12 qualification and could thus be regarded as educated, education in financial management seemed to be lacking. Educating SMME owners in small business financial management could improve financial management practices and thus contribute to business success. The importance of financial practices, the efficiency of generating accounting information and the efficiency of reporting and analysis all received high ratings in our survey, which correlates well with the findings of Abanis et at (2013).

As financial practices increase in complexity, the use of external expertise becomes more prevalent. In our study, about half of the owners were involved in reporting accounting information, fewer than half recorded business transactions and about a quarter prepared and interpreted accounting reports and these low proportions could be ascribed to a lack of financial management competence. More importantly, by relying on external individuals or companies for interpretation and analysis, owners may lose flexibility in decision making.

From this study, it is evident that SMMEs use ratios to a limited extent, with current ratios and return on sales as the two most commonly used. Initially, 13 ratios were included in the questionnaire, but only six were used by respondents (and those six to a limited extent 
only). This limited use is a cause for concern, because the monitoring of financial ratios can provide an early warning of liquidity and profitability problems.

The results of the study are surprising, given the high-level educational background of the owners. SMME owners seem to lack knowledge and application of financial management practices, even though a high percentage indicated that they had attended financial management training. We can speculate that perhaps the particular training they had undertaken was not effective, or that the SMME owners had perhaps not applied the knowledge gained from the training to their businesses. It is the case that many higher educational institutions in South Africa focus on financial management in large corporations rather than in small businesses: very few institutions include financial management topics focusing on SMMEs.

We would argue that higher education institutions with faculties offering courses in economic and management sciences should place more emphasis on the application of financial management topics to SMMEs. Research by Wolmarans ( 1999) indicated a financial management education gap between academics and practitioners in large businesses in South Africa : this may also be the case with SMMEs. More consultations are needed between higher education institutions and business owners on action needed to close this gap, so that SMMEs can adopt the financial management practices that are most appropriate for the operation of their business.

\section{Conclusions}

In this study we examined the financial management practices of SMMEs, the perceived importance of the accounting information system and the use of financial analysis and reporting.

Most of the SMME owners had a post-Grade 12 qualification and most had been exposed to some financial management training but lacked the expertise or willingness to apply it.to their business. With regard to financial planning , 80\% of owners felt that this was very important. More than half the SMMEs used external accountants to prepare accounting reports and more than $60 \%$ relied on external accountants to interpret and use accounting information. This suggests that a high percentage of the owners lacked the ability to analyse and interpret financial statements, although $80 \%$ recognized the importance of accounting information in making decisions; and 64\% used analyses of financial statements produced by external accountants when making their business decisions. Financial ratio analysis was used to a limited extent only by the SMMEs.

\section{Recommendations}

Based on our findings, we offer the following recommendations .

(I) Courses offered by business support organizations should be developed and tailored to suit the needs of SMME owners in specific sectors. 
(II) There should be presentations or workshops on financial management organized by the Chambers of Commerce and SETAs (Sector Educa tion and Train ing Authorities).

(III) Higher education institutio ns offering entrepreneurship or business-related modules should place more emphasis on financial management topics targeted at SMMEs rather than large businesses.

(IV) (4) For those higher education institutions offering financial management courses, the following topics in particular should receive more attention: the role of finance in the bu siness; the income statement and balance sheet; cash budgets ; operating budgets; and understanding a d interpretation of financial statements.

\section{Limitations and future research}

This study is based on a small sample of 59 cases and was limited to the City of Cape Town in the Province of the Western Cape. It is an exploratory study, setting the stage for further rigorous research in the field, especially in South Africa where there is a scarcity of research on financial management. We suggest that future studies should include (i) more cases and (ii) other less researched practices, such as working capital budgeting, management accounting and financial analysis. This would then enable results to be generalized, to provide a better and more detailed picture of which practices are followed by SMMEs. 


\section{References}

Abanis , T., Sunday,A., Burani, A ., and Eliabu, B. (2013), 'Financial management practices in small and medium enterprises In selected districts in Westem Uganda', Research Journal of Finance and Accounting, Vol 4, No 2, pp 29-42 .

Abdullah ,F.,Hamali,J., Deen,A.A., Saban,G., and Abg Abdulrahman, A.Z . (2009), 'Developing a framework of success of Bumiputra entrepreneurs ', Journal of Enterprising Communities: People and places in the Global Economy. Vol 3, No 1,pp 8-24.

Armstrong,W.(1986),A Handbook of Management Techniques. 1st edition,Kogan Page, London.

Armstrong,W. (2001). A Handbook of Management Techniques, 3rd edition,Kogan Page, London.

Babble, E. (2007), The Practice of Social Research, Thomson Wadsworth ,Belmont, CA.

Babble, E. and Mouton, J.(2001), The Practice of Social Research, Oxford University Press, Cape Town.

Berry, J.A., Sweeting, A., Cassim,A.,Kasper, A., Rajaratnam, B., and Seventer, D.E. (2002), The Economies of SMMEs in South Africa, http://www.tips.org.za/506.pdf (accessed 15 May 2007).

Berry, J.A., Sweeting, R.and Goto, J. (2006), The effects of business advisers on the performance of SMEs',Journal of Small Business and Enterprise Development, Vol 13,No 1, pp 33-47.

Blackburn, R.,Carey, P.and Tanewski, G.A. 2010, 'The role of competence, trust and professional ethics in the supply of external business advice by accountants to SMEs',Research Report, Association of Chartered Certified Accountants (see: http://www accaglobal.com).

Blackburn, R., Eadson,W., Lefebvre,A. and Gans, P. (2006), 'SMEs, regulation and the role of the accountanf, ACCA Research Report No 96, ACCA, London.

Brinckmann,J., Salomo, S. and Gemueden,H.G.(2011), 'Financial management competence founding teams and growth of new technology-based firms' ,Entrepreneurship Theory and Practice, Vol 35,No 2, pp 217-243 .

Bruwer, J.P. (2010), 'Sustainability of South African FMCG SMME retail businesses in the Cape Peninsula',MTech Thesis (Internal Auditing), Cape Peninsula University of Technology, Bellville.

Department of Trade and Industry (1995), 'National strategy for the development and promotion of small business in South Africa', White Paper on Small Business, DTI,Pretoria.

Department of Trade and Industry (2003), 'State of small business development in South Africa:annual review 2002', DTI,Pretoria.

Department of Trade and Industry (2008) The DTI Group SMME Services 2008, DTI, Pretoria.

Dodge,H.R. and Robbins,J.E. (1992),An empirical investigation of the organisationallife cyc le model for small business development and survival',Journal of Small Business Management, Vol 30, No 1, pp 27-37. 
Doving, E. and Gooderham, P.N. (2008),'Dynamic capabilities as antecedents pf the scope of related diversification:the case of small firm accountancy practices', Strategic Management Journal, Vol29,No 841-857.

Everaert, P., Sarens, G. and Rommel, J. (2006), Outsourcing of Accounting tasks in SMEs: An Extended TCE model, University of Gent, Kuiperskaai.

Fatoki, o. (2012), 'The impact of entrepreneurial orientation on access to debt finance and performance of small and medium enterprises in South Africa' .Journal of Social Science, Vol 32, No 2, pp 121-131.

Firer,C., Ross, S.A., Westerfield, W. and Jordan. B.D. (2004), Fundamentals of Corporate Finance, McGraw-Hill, Maidenhead.

Gitman, L.J. (2003), The Principles of Managerial Finance, Pearson Education, New York.

Harif,M.,Osman, H.B.and Hoe,C.H. (2010),'Financial management practices:an indepth study among CEOs of small and medium enterprises (SMEs)', International Review of Business Research Papers, Vol 6, No 6, pp 13-35.

Herrington, M.and Wood, E. (2004) Global Entrepreneurship Monitor - South Africa Executive Report 2003 Update, Graduate School of Business, University of Cape Town, CapeTown.

IFC (2006),Access to Finance for Women entrepreneurs in South Africa, International Finance Corporation, Johannesburg .

Ismail,A.N.and Zin, M.A . (2009), 'Usage of accounting information among Malaysian Bumiputra small and medium non-manufactur ing firms', Journal of Enterprise Resource Planning Studies, Vol 2009, 7 pp, see :http:// www.ibimapublishing.com oumals/JERPS/2009/ 101113.pdf (accessed 27 August 2014).

Jayansankaran,S. (1999), 'Malay dilemma', Far Eastern Economic Review, Vol 162, No 18, pp 50.

Keown, A., Martin, J.D., Petty, W.J.and Scott, D.F. (2002), Financial Management: Principles and Applications, 9th edition, Prentice-Hall,Upper Saddle River,NJ.

Lee, S.and Filbeck,G.(2000), Financial management techniques in family businesses', Family Business Review, Vol13, No 3, pp 201-216.

Maseko, N.and Manyani,o. (2011),'Accounting practices of SMEs in Zimbabwe :an investigative study of record keeping for performance measuremenf, Journal of Accounting and Taxes, Vol3, No 8, pp 171-181.

Mcmahon,R.P.G. (1999), 'Putting SME financial reporting into theoretical and practicalperspective', Research Paper Series 98-100, Flinders University,Adelaide.

McMahon,R.P.G.and Davies,L.G. (1994), 'Financial reporting and analysis practices in small enterprises: their assoc iation with growth rate and financial performance',Journal of Small Business Management, Vol 32,No 1,pp 9-17.

Nayak,A. and Greenfield,S. (1994), 'The use of management accounting information for managing micro businesses', in Hughes, A, and Storey, D.E., eds, Finance and the Small Firm, Routledge, London. 
Nguyen,K.M.(2001),'Financial management and profitability of small and medium enterprises', Doctor of Business Administration thesis, Southern Cross, Ho Chi Min City, Vietnam.

Oduware, U. (2011), Overview of Financial Management, http://www.isearch .im/pdf/1/chapter-1-overview-of-flnancia l- management.html (accessed 18 July 2013).

OECD 2006), The SME Financing Gap, Volume 1:Theory and Evidence,http://www.insine .org/documenti/ sme_financing_gap _oced.pdf \{accessed 13 July 2007).

Ooghe, H.(1998), 'Financial management practices in China: a case study approach to companies in the Shangai region', European Business Review, Vol 98,No 4,pp 217-226.

Padachi, K. (2010), 'Accounting services among manufacturing SMEs: a neglected subject', http://www.oum ac.mu/sites/ irssm/papers/Padachi -2045.pdf (accessed 15 July 2013).

Perren, L. and Grant, P. \{2000), 'The evolution of management accounting routines in small businesses: a social constructive perspective', Management Accounting Research, Vol11, No 4, pp 391-411.

Petrus, H.G.\{2009), 'An investigation into causes of success and failure in small businesses with the Department of Social Development in the Eastern Cape', Master's Degree thesis, Rhodes University, Grahamstown.

Pullen, R.J. and Cooley,P.(1979) ,'Small business cash management practices'. American Journal of Small Businesses, Vol4, No 2,pp 1-11.

Robson, C. (2002), Real World Research: A Resource for Social Scientist and Practioner-Researchers, Blackwell, Oxford.

Sha, S. (2006),'An investigation into problems facing small-to-medium-sized enterprises in achieving growth in the Eastern Cape :enhanc ing the strategy for developing small growth potential firms in the Eastern Cape', Master of Commerce thesis, Rhodes University, Rhodes.

Tung, R.L. and Aycan, Z.(2008), 'Key success factors and Indigeneous management practices in SMEs in emerging economies', Journal of World Business, Vol 43, No 4, pp 381-384.

Viyakumar, A. (2001), Working Capital Management : A Comparative Study, Northern Book Center, New Delhi. 350

Weygandt, J.J., Kieso, D.E. and Kimmel, P.D.(2000), Financial Accounting, John Wiley, New York.

Wolmarans , H.P. (1999), 'Financ ial management education: is there a gap between academics and practioners?', South African Journal of Economics and Management Science, Vol 2, No 3, pp 523-535. 